UDC 66.012/663.5:661.725.3

\title{
CONTROL OF THE DIRECT HYDRATION PROCESS OF PROPYLENE IN ACCORDANCE WITH ITS DYNAMICS
}

\author{
A.M.Aliyev, A.R.Safarov, I.V.Balayev, A.M.Guseynova, R.Y.Agayeva, F.G.Bayramov* \\ M.Nagiyev Institute of Catalysis and Inorganic Chemistry, NAS of Azerbaijan \\ *Azerbaijan State Oil and Industry University \\ agil_s@mail.ru \\ Received 05.03.2019
}

\begin{abstract}
The article offers calculation of the hydration process proceeding under non-stationing conditions, caused by the removal of phosphoric acid from the carrier and leading to a decrease in the productivity of isopropyl alcohol. For maintaining the stable operation of the catalyst the control function has been proposed of which taking into account in the mathematical model of the process allows keeping the productivity of isopropyl alcohol at the constant level.
\end{abstract}

Keywords: hydration, propylene, isopropyl alcohol, addition of phosphoric acid control.

https://doi.org/10.32737/0005-2531-2019-3-15-19

\section{Problem statement}

Isopropanol is one of the large-scale and widely used products of organic synthesis. It is a good, although flammable, solvent; widely used in medicine as an antiseptic; the substance is indispensable in the processing of petroleum, in pharmacology, also in cosmetology, in the chemical and furniture industry. It is used to synthesize acetone, hydrogen peroxide, isopropylamine, isopropyl acetate, surfactants and some pharmaceutical preparations.

Isopropanol is currently produced by direct hydration of propylene. The catalyst for the direct hydration process is phosphoric acid on a solid carrier - silicagel. In industrial conditions the process is carried out at a temperature of $180-220^{\circ} \mathrm{C}$ and pressure (3-4) MPa. The molar ratio of water steam:propylene $-(0.4-0.6): 1$; selectivity of isopropyl alcohol is $95.5 \%[1,2]$. The service life of the catalyst is $400-500$ hours. The activity of the catalyst during operation decreases due of the removal of acid.

In the work [3], it is proposed continuously add $\mathrm{H}_{3} \mathrm{PO}_{4}$ to the vapor-gas mixture at the reactor inlet, which ultimately will lead to a large consumption of it. We propose the more expedient method - the method of periodic supply of phosphoric acid due to which the consumption of acid will be significantly reduced. For monitoring the course of the process we enter the control function $\theta$, equal to the ratio of the current and initial values of phosphoric acid: $\theta=G_{\text {тек }} / G_{\text {исх }}$, actually means the share of its active centers, changing during the operation of the catalyst due to partial acid loss.

Introducing it into the mathematical model of the process proceeding in stationary conditions will keep the productivity of isopropyl alcohol at the optimal level for industry and, in addition, will significantly reduce the cost of the process.

Calculation of the process according to the method of periodic feeding

During the starting period of the hydration process (50-100 hours), the maximum removal rate of the acid is observed. However, despite this taking into account the thermodynamic limitations, the amount of acid is still quite large, so the degree of conversion of propylene remains equal to the maximum possible -4-5)\%. During this period the development of the catalyst occurs at which its stable activity is achieved, corresponding to the indicated degree of conversion. The values of $\theta$ in the starting period are close to one. Eventually they decrease. Therefore, in order to preserve the stability of the catalyst, we take $\theta=0.98$ as the criterion value of the control function, when the difference between the current and initial values of phosphoric acid is still small. The accepted 
value of $\theta$ will be adhered throughout the life of the catalyst, assuming that within each 50 hours the removal rate of the acid and the corresponding value of $\theta$ remain almost constant. As experience shows that difference of $\theta$ from the value of 0.98 by approximately $1-2 \%$ will already have an effect on the activity of the catalyst and, accordingly, on the output of isopropyl alcohol.

The maximum rate of removal of the phosphoric acid in the starting period for the amount used in the process of $6500 \mathrm{~kg}$ is $1.5 \mathrm{~kg} / \mathrm{h}$. Then it gradually decreases to $(0.05-0.1) \mathrm{kg} / \mathrm{h} \mathrm{[3]}$.

Calculating the process is presented in Table 1.

At the distribution of the rate of removal of phosphoric acid values over time intervals (50 hours with catalyst life of 500 hours), observed in industry (column 2 of Table 1), the quantities of phosphoric acid $G_{\text {rem }}$ which taking out every 50 hours are presented in column 3 . The remaining current values of $G_{\text {curr }}$ and the corresponding values of the control function $\theta$ are presented in columns 4 and 5 .

As we can see, in the industrial implementation of the process, when the rate of removal of phosphoric acid is equal to the speed of its continuous supply [3], the adopted value $\theta=0.98$ is violated immediately after the starting period of the catalyst: after 150 hours of operation, $\theta$ decreases to 0.9661 and eventually continues to decrease, i.e. catalyst activity (or the share of its active centers) drops significantly. In this case, taking away, and, therefore, it is brought into the reactor for 500 hours of operation $523.125 \mathrm{~kg}$ of phosphoric acid (with its continuous supplying). In order to avoid a large consumption of the catalyst, it is proposed for each time when $\theta$ deviates from the accepted value of 0.98 to add to the remaining amount of phosphoric acid such an additional amount of it, which would lead the catalyst to a stable state.

In this case, the control function will take the form: $\theta^{\prime}=\frac{G_{\text {curr }}+G_{\text {add }}}{G_{\text {init }}^{\prime}}=\frac{G_{\text {curr }}^{\prime}}{G_{\text {init }}^{\prime}}$, where the obtained value $G_{\text {curr }}^{\prime}$ at this time interval became the initial $G_{\text {curr }}^{\prime}$ for the following intervals. As we can see from the Table, periodic supplements of phosphoric acid (in the amount of $248.473 \mathrm{~kg}$ ) instead of continuously supplying it, allow to maintain stable operation of the reactor during the whole period of its operation, and also significantly reduce the consumption of phosphoric acid (248.473 kg instead of $523.125 \mathrm{~kg}$ ).

Table 1. Comparison of the results of the calculation of the hydration process by industrial and proposed method for its implementation

\begin{tabular}{|c|c|c|c|c|c|c|c|}
\hline \multicolumn{5}{|c|}{ Industrial method } & \multicolumn{3}{|c|}{ Proposed method } \\
\hline $\begin{array}{l}\text { the time } \\
\text { intervals } \\
\text { of the } \\
\text { catalyst, } \\
\mathrm{h}\end{array}$ & $\begin{array}{c}\text { rate of } \\
\text { removal of } \\
\text { phosphoric } \\
\text { acid, (by } \\
\text { interval) } \\
\mathrm{kg} / \mathrm{h}\end{array}$ & $\begin{array}{l}\text { the amount of } \\
\text { phosphoric } \\
\text { acid removal } \\
\text { in every } 50 \mathrm{~h} \text {, } \\
G_{\text {rem }}, \mathrm{kg}\end{array}$ & $\begin{array}{l}\text { the current } \\
\text { amount of } \\
\text { phosphoric } \\
\text { acid, } \\
G_{\text {curr }}, \mathrm{kg}\end{array}$ & $\begin{array}{l}\text { control func- } \\
\text { tion } \\
\theta=G_{\text {curr }} / G_{\text {init }} \\
\text { (without } \\
\text { additives) }\end{array}$ & $\begin{array}{c}\text { additives of } \\
\text { phosphoric } \\
\text { acid, } \\
G_{\text {add }}, \mathrm{kg}\end{array}$ & $\begin{array}{c}\text { the current } \\
\text { amount of } \\
\text { phosphoric } \\
\text { acid, kg } \\
G_{\text {curr }}^{\prime}=G_{\text {curr }}+G_{\text {add }}\end{array}$ & $\begin{array}{c}\begin{array}{c}\text { control } \\
\text { function }\end{array} \\
\theta^{\prime}=\frac{G_{\text {curr }}+G_{\text {add }}}{G_{\text {init }}^{\prime}} \\
\text { (without } \\
\text { additives) }\end{array}$ \\
\hline 0 & 0 & 0 & 6500 & 1 & - & - & - \\
\hline $0-50$ & 1.5 & 75 & 6425 & 0.9885 & - & - & 0.98 \\
\hline $50-100$ & 1.46 & 73.125 & 6351.875 & 0.9772 & - & - & 0.97 \\
\hline $100-150$ & 1.42 & 71.25 & 6280.625 & 0.9661 & 89.375 & 6370 & 0.98 \\
\hline $150-200$ & 1.35 & 67.5 & 6213.125 & 0.9559 & - & - & 0.98 \\
\hline $200-250$ & 1.27 & 63.75 & 6149.375 & 0.946 & 93.225 & 6242.6 & 0.96 \\
\hline $250-300$ & 1.05 & 52.5 & 6096.875 & 0.938 & - & - & 0.98 \\
\hline $300-350$ & 0.9 & 45 & 6051.875 & 0.9311 & 65.873 & 6117.7 & 0.96 \\
\hline $350-400$ & 0.75 & 37.5 & 6014.375 & 0.9253 & - & - & 0.98 \\
\hline $400-450$ & 0.6 & 30 & 5984.375 & 0.9206 & - & - & 0.98 \\
\hline $450-500$ & 0.15 & 7.5 & 5976.875 & 0.9195 & - & - & 0.98 \\
\hline & & $\sum 523.125$ & & & $\sum 248.473$ & & \\
\hline
\end{tabular}


By the least squares method [4] using the data of table 1 has been determined the regression dependence to control the hydration process:

$$
y=G_{\text {curr }}=\mathrm{f}(\tau)=0.0014 \cdot \tau^{2}-1.7754 \cdot \tau+6508.8,(1)
$$

by which it is possible at any time to determine the current value of phosphoric acid $\left(G_{\text {curr }}\right)$ and the corresponding value of $\theta$. Graphically, it is presented in Figure 1.

The dynamics of the change in the control function over time is clearly seen in Figure 2, where the segments below the $\theta(\tau)$ curve mean the quantities of phosphoric acid in the industrial process taking away at the relevant time stage (according Table 1), and the shaded segments above the curve are those of phosphoric acid we propose to add to the reactor the amount of acid remaining in this time interval in order to comply with the accepted value of $\theta=0.98$, i.e. returning the catalyst to a stable state. As we see in Table 1, they correspond to the addition of phosphoric acid in the amount of $248.473 \mathrm{~kg}$.

The shaded area is the area of stable catalyst activity for $0.98<\theta<1$.

Our proposed method of periodic addition of phosphoric acid will significantly reduce the total consumption of acid and maintaining the stability of the catalyst for all 500 hours.

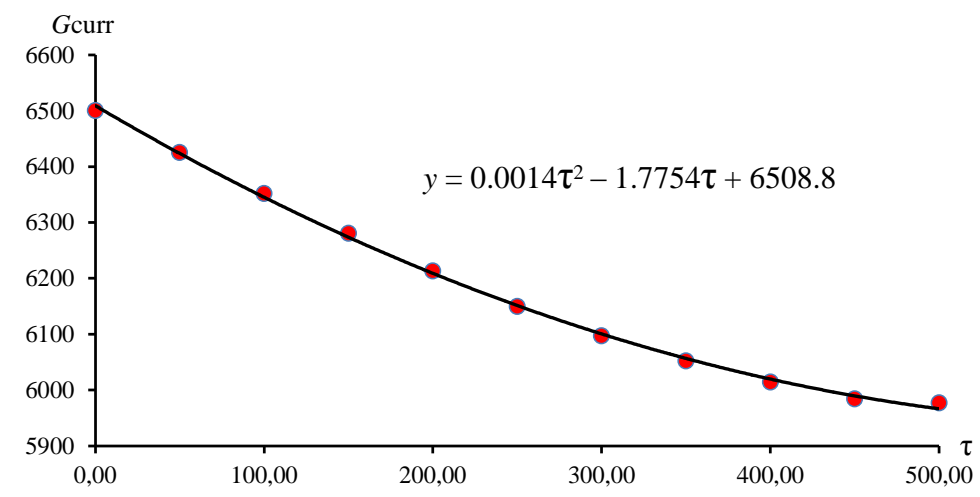

Fig.1. Time dependence of change in the amount of phosphoric acid.

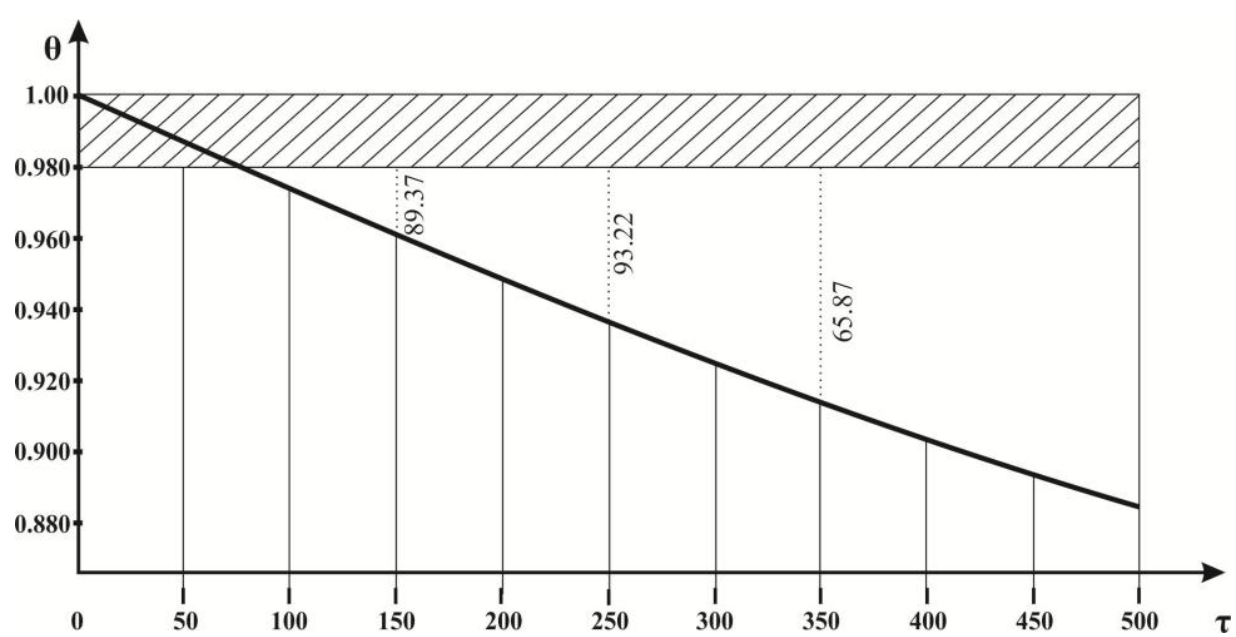

Fig. 2. Dynamics of change in control function $\theta$ in the course of time $\tau$. 
Mathematical model of the process with taking into account its non-stationarity

The main reaction in the hydrator is the formation of isopropyl alcohol:

$\mathrm{CH}_{3}-\mathrm{CH}=\mathrm{CH}_{2}+\mathrm{H}_{2} \mathrm{O} \leftrightarrow \mathrm{CH}_{3}-\mathrm{CH}(\mathrm{OH})-\mathrm{CH}_{3}$. (2)

The kinetic equation corresponding to this stoichiometric scheme has the form [3]:

$$
\frac{\mathrm{d} x}{\mathrm{~d} t}=k_{1} P\left[\left(\frac{P_{\mathrm{H}_{2} \mathrm{O}}^{0}}{P}-x\right)\left(\frac{P_{\mathrm{C}_{3} \mathrm{H}_{6}}^{0}}{P}-x\right)-\frac{x}{K_{\mathrm{R}} P}\right],
$$

where $x=\frac{P_{\mathrm{IPA}}}{P}$.

Kinetic constants:

$$
\begin{aligned}
& k_{1}=9.467 \cdot 10^{9} \exp ^{-\frac{26900}{R T}} \\
& \lg K_{\mathrm{R}}=\frac{1920}{T}-5.88,
\end{aligned}
$$

where $K_{\mathrm{R}}$ - equilibrium constant, $1 / \mathrm{Pa} ; k_{1}-$ rate constant of alcohol formation, $1 /(\mathrm{Pa} \cdot \mathrm{s}) ; P$ total pressure of the system, $\mathrm{Pa} ; P_{\mathrm{H}_{2} \mathrm{O}}^{0}, P_{\mathrm{C}_{3} \mathrm{H}_{6}}^{0}-$ partial pressures of water and propylene at the inlet to the reactor, $\mathrm{Pa} ; P_{\mathrm{IPA}}-$ partial pressure of isopropyl alcohol, $\mathrm{Pa} ; t$ - residence time in the reactor, $\mathrm{s} ; x$-conversion of propylene.

This model was developed for stationary conditions of the process without taking into account the loss of catalyst activity over time.

Entering the process control function $\theta$ into the kinetic model of the process proceeding under stationary conditions (3), we obtain the non-stationary kinetic model:

$$
\frac{\mathrm{d} x}{\mathrm{~d} t}=k_{1} P\left[\left(\frac{P_{\mathrm{H}_{2} \mathrm{O}}^{0}}{P}-x\right)\left(\frac{P_{\mathrm{C}_{3} \mathrm{H}_{6}}^{0}}{P}-x\right)-\frac{x}{K_{\mathrm{R}} P}\right] \cdot \theta
$$

In deriving the equation of the heat balance were taken into account the heat of the chemical reaction for producing of isopropyl alcohol and the heat going to heat the olefin:

$$
\frac{4}{\rho_{\mathrm{kat}} \pi D^{2}} \frac{\mathrm{d} T}{\mathrm{~d} l}=-\frac{\sum r \Delta H_{\mathrm{R}}}{\sum_{i=1}^{3} n_{i} C_{p i}(\overline{1,3})}-\mathrm{Q}_{\text {heat }}
$$

To account for the pressure drop along the length of the reactor was used the Ergun equation [5]:

$$
\frac{\mathrm{d} P}{\mathrm{~d} l}=-\left(\frac{150}{\operatorname{Re}}+1.75\right) \cdot \frac{\rho_{\mathrm{qaz}} u_{0}^{2}(1-\varepsilon)}{d_{\mathrm{p}} g \varepsilon^{3}} \cdot 0.987 \cdot 10^{-5},
$$

where $T$ - reaction temperature, $\mathrm{K} ; \rho_{\mathrm{kat}}-$ catalyst density, $\mathrm{kg} / \mathrm{M}^{3} ; \quad r$ - rate of reaction, $\mathrm{mol} /\left(\mathrm{kg}_{\mathrm{kat}} \mathrm{h}\right) ; C_{p i}$ - heat capacity of the $i$-th component, $\mathrm{kcal} /(\mathrm{mol} \mathrm{qrad}) ; \Delta H_{\mathrm{R}}$ - heat of reaction, $\mathrm{kcal} / \mathrm{mol} ; Q_{\text {naq }}$ - the heat going to heat the propylene, $\mathrm{kcal} / \mathrm{mol} ; n_{i}-$ the current number of moles of the $i$-th component, mol/h; Re Reynolds criterion equal to $\frac{d_{\mathrm{p}} \rho_{\mathrm{qaz}} u_{0}}{\mu(1-\varepsilon)} ; D-$ diameter of reactor, $\mathrm{m} ; \rho_{\mathrm{qaz}}-$ gas density, $\mathrm{kg} / \mathrm{m}^{3} ; \mathrm{g}-$ acceleration of gravity, $\mathrm{m} / \mathrm{se} ; u_{0}-$ linear velocity, $\mathrm{m} / \mathrm{c} ; d_{\mathrm{p}}$ - equivalent diameter of particles, $\mathrm{m}$; $\varepsilon$ - porosity, $\mathrm{d} / \mathrm{q} ; \quad \mu-$ gas viscosity, $\mathrm{kg} /(\mathrm{m}$ $\mathrm{s}) ; l$ - length of reactor, $\mathrm{M}$.

The equation of the kinetic model (6) together with the equations of heat balance (7) and pressure loss (8) form the complete mathematical model of the process of direct hydration of propylene taking into account the nonstationarity of its flowing.

\section{Conclusion}

Using this model allow us to maintain the performance of isopropyl alcohol at the desired (stationary) level with the lowest expenditure on the consumption of phosphoric acid.

\section{References}

1. Lebedev N.N. Teoriia himicheskikh protcessov osnovnogo organicheskogo i neftehimicheskogo sinteza. M.: Himiia. 1988. 588 s.

2. Zhuravlev V.A. Raschet materialnykh balansov pri proektirovanii proizvodstv organicheskogo sinteza. Uchebnoe posobie. Kemerovo: KuzGTU, 2012. $92 \mathrm{c}$.

3. Tekhnologicheskii reglament dlia proektirovaniia proizvodstva izopropilovogo spirta moshchnostiu 100 tys. t/god v sostave Sumgaitskogo PO "Sintezkauchuk". 1989 g. 138 s.

4. Balayev V.A., Məmmədov N.S. İdarəetmə obyektlərinin riyazi modellərinin alınması. Bak1, 2010. $411 \mathrm{~s}$.

5. Beloglazov I.N., Golubev V.O. Osnovy rascheta filtratcionnykh protcessov. - M.: Izdatelskii dom "Ruda i Metally". 2002. 210 s. 


\title{
PROPILENIN BİRBAŞA HIDRATASIYYASI PROSESININ DINAMIKASINI NOZəRӘ ALMAQLA İDARə EDİLMOSi
}

\begin{abstract}
A.M.Aliyev, A.R.Safarov, I.V.Balayev, A.M.Quseynova, R.Y.Agayeva, F.G.Bayramov
Məqalədə propilenin birbaşa hidratasiyası prosesində fosfor turşusunun daşıyıcıdan azalması səbəbindən qeyri-stasionar şəraitdə izopropil spirtinin məhsuldarlığının aşağı düşməsinin hesablanmasının aparılması göstərilib. Katalizatorun stabil işinin saxlanılması üçün idarəetmə funksiyası təklif olunub. Bu funksiyanı prosesin riyazi modelinə daxil etməklə izopropil spirtinin məhsuldarlığını daimi səviyyədə saxlanılmasına imkan verəcək.

Açar sözlor: hidratasiya, propilen, izopropil spirti, fosfor turşusunun alavasi, idarəetma.

\section{УПРАВЛЕНИЕ ПРОЦЕССОМ ПРЯМОЙ ГИДРАТАЦИИ ПРОПИЛЕНА С УЧЕТОМ ДИНАМИКИ ЕГО ПРОТЕКАНИЯ}

\section{А.М.Алиев, А.Р.Сафаров, И.В.Балаев, А.М.Гусейнова, Р.Ю.Агаева, Ф.Г.Байрамов}

Приводится расчет процесса прямой гидратации пропилена, протекающего в нестационарных условиях, вызванных уносом фосфорной кислоты с поверхности носителя и приводящих к снижению производительности установление (реактора) синтеза изопропилового спирта. Для поддержания стабильной работы катализатора предложена функция управления, учет которой в математической модели процесса позволит поддерживать производительность реактора по изопропиловому спирту на постоянном уровне.
\end{abstract}

Ключевые слова: гидратация, пропилен, изопропиловый спирт, подпитка фосфорной кислотой, управление. 